\begin{tabular}{ccl}
\hline Jurnal Teknologi Kimia Unimal & $\begin{array}{l}\text { Jurnal } \\
\text { Teknologi } \\
\text { http://ojs.unimal.ac.id/index.php/jtk }\end{array}$ & $\begin{array}{l}\text { Kimia } \\
\text { Unimal }\end{array}$ \\
\hline
\end{tabular}

\title{
PEMANFAATAN LIMBAH KALENG MINUMAN ALUMINIUM UNTUK PRODUKSI GAS HIDROGEN MENGGUNAKAN KATALIS KALIUM HIDROKSIDA (KOH)
}

\author{
Lentina Sitohang ${ }^{1}$, Lukman Hakim $^{1}$, Fikri Hasfita ${ }^{1}$ \\ ${ }^{1}$ Jurusan Teknik Kimia, Fakultas Teknik, Universitas Malikussaleh \\ Laboratorium Teknik Kimia, Jl. Batam No. 2, Bukit Indah, Lhokseumawe 24353 \\ e-mail : lentinasitohang536@gmail.com
}

\begin{abstract}
Abstrak
Permintaan gas $\mathrm{H}_{2}$ sebagai sel bahan bakar (fuel cell) semakin besar, bahkan diperkirakan bahwa gas $\mathrm{H}_{2}$ ini akan dijadikan sumber energi terbarukan pada masa yang akan datang. Oleh karena itu perlu dilakukan penelitian untuk memproduksi gas hidrogen dari limbah kaleng minuman aluminium dengan katalis kalium hidroksida $(\mathrm{KOH})$. Metode yang digunakan pada penelitian ini adalah reaksi kimiawi antara aluminium sebanyak $0.5 \mathrm{~g}, 1 \mathrm{~g}, 1.5 \mathrm{~g}$, dan $2 \mathrm{~g}$ dengan larutan $\mathrm{KOH}$ pada konsentrasi yang berbeda-beda $(2 \mathrm{~N}, 3 \mathrm{~N}, 4 \mathrm{~N}, 5$ $N$,dan 6 N) masing-maing sebanyak 25 mL selama 60 menit. Dari hasil penelitian diperoleh volume dan yield gas hidrogen tertinggi yaitu pada 2 gram aluminium, $\mathrm{KOH} 6 \mathrm{~N}$ sebesar 2,025.10-3 m3 dan 7,23\%. Konversi aluminium menjadi produk tertinggi diperoleh pada 0,5 gram aluminium, KOH $6 \mathrm{~N}$ sebesar 86,97\%.

Kata kunci: limbah kaleng minuman, aluminium, $\mathrm{KOH}$, hidrogen, yield
\end{abstract}

\section{Pendahuluan}

Kaleng yang terbuat dari aluminium biasanya digunakan oleh industri minuman ringan (soft drink) sebagai kemasan dari minuman tersebut. Contohnya, PT. Coca-cola Amatil Indonesia yang memproduksi minuman coca-cola dengan kapasitas 30.000 botol/jam pada tahun 2014 dan bahkan saat ini perusahaan tersebut sedang mengincar produksi 450.000.000 liter dari sebelumnya (Galih, 2015). Salah satu cara teknologi yang dapat dikembangkan untuk mengolah limbah kemasan kaleng minuman bekas (soft drink) tersebut adalah dengan cara daur ulang. Karena daur ulang merupakan salah satu cara pengelolahan limbah yang sangat efisien dalam menghasilkan suatu produk yang mempunyai nilai ekonomis serta ramah lingkungan. 
Kaleng minuman aluminium pada umumnya di bagian dalamnya mempunyai lapisan plastik yang tipis, bagian luarnya biasanya dilapisi oleh cat tipis. Pelapisan ini harus dihilangkan sebelum reaksi-reaksi kimia dengan logam dapat terjadi. Berikut reaksi pembentukan gas hidrogen pada pembuatan alum dari aluminium:

$$
2 \mathrm{Al}_{(\mathrm{s})}+2 \mathrm{OH}^{-}(\mathrm{aq})+6 \mathrm{H}_{2} \mathrm{O}_{(\mathrm{liq})} \rightarrow 2 \mathrm{Al}_{\left(\mathrm{OH}_{4}^{-}\right)}{ }_{(\mathrm{aq})}+3 \mathrm{H}_{2}(\mathrm{~g})
$$

Pembentukan gas hidrogen diperoleh dalam pembuatan alum (tawas) dari aluminium, secara teoritis didasarkan pada sifat amfoter dari hidroksida aluminium. Jika logam aluminium direaksikan dengan larutan $\mathrm{KOH}$ dengan konsentrasi tertentu, maka tahap pertama akan terjadi endapan hidrolisa aluminium (Louis, 1963). Siregar (2010) menarik kesimpulan bahwa gas hidrogen dapat diproduksi dari limbah aluminium foil atau limbah kaleng minuman menggunakan katalis basa dengan hasil produksi hidrogen optimum yang diperoleh adalah sebesar 0,006 gram dari 0,05 gram limbah aluminium (aluminium foil). Penelitian tentang produksi $\mathrm{H}_{2}$ dari kaleng bekas dilanjutkan oleh Agus dan Jajang (2014) dengan mereaksikan kaleng bekas dengan air menggunakan soda api dan hidrogen berhasil dimanfaatkan sebagai suplemen bahan bakar mesin diesel pada sistim dual fuel menghasilkan pengurangan konsumsi solar paling tinggi mencapai $52 \%$.

Seiring dengan perkembangan teknologi, permintaan gas $\mathrm{H}_{2}$ semakin besar terutama untuk bahan bakar tidak berpolusi, sel bahan bakar (fuel cell), bahkan diperkirakan bahwa $\mathrm{H}_{2}$ ini akan dijadikan sumber energi terbarukan pada masa yang akan datang. Oleh karena itu, perlu dilakukan penelitian untuk memproduksi gas hidrogen dari limbah kaleng minuman aluminium dengan katalis kalium hidroksida $(\mathrm{KOH})$.

\section{Tinjauan Pustaka}

Hidrogen (bahasa Latin: hydrogenium, dari bahasa Yunani: hydro: air, genes: membentuk) adalah unsur kimia pada tabel periodik yang memiliki simbol $\mathrm{H}$ dan nomor atom 1. Pada suhu dan tekanan standar, hidrogen tidak berwarna, tidak berbau, bersifat non-logam, bervalensi tunggal, dan merupakan gas diatomik 
yang sangat mudah terbakar. Dengan massa atom 1,00794 dan densitas 0,08988 g/L pada $0^{\circ} \mathrm{C}$ (Henry, 1766). Adapun sifat kimia dari gas hidrogen adalah gas hidrogen sangat mudah terbakar dan akan terbakar pada konsentrasi serendah $4 \%$ di udara bebas. Hidrogen terbakar menurut persamaan kimia:

$$
2 \mathrm{H}_{2(\mathrm{~g})}+\mathrm{O}_{2(\mathrm{~g})} \rightarrow 2 \mathrm{H}_{2} \mathrm{O}_{(\mathrm{l})}+572 \mathrm{~kJ}(286 \mathrm{~kJ} / \mathrm{mol})
$$

Perapuhan hidrogen dapat terjadi pada kebanyakan logam dan hidrogen sangat larut dalam berbagai senyawa yang terdiri dari logam tanah nadir, logam transisi, dan dapat dilarutkan dalam logam kristal maupun logam amorf (Khairunnisa, 2013). Hidrogen adalah unsur yang ditemukan oleh Hendry Cavendish (1731-1810) dan merupakan unsur yang atomnya paling kecil dan ringan serta paling banyak terdapat di alam semesta. Hidrogen bergabung dengan unsur-unsur dari keluarga karbon (IVA), nitrogen (VA), oksigen (VIA), dan halogen (VIIA), sebaik dengan $\mathrm{Be}, \mathrm{Mg}, \mathrm{B}, \mathrm{Al}$ dan $\mathrm{Ga}$ membentuk hibrida kovalen. $\mathrm{H}_{2}$ (c) mempunyai rapatan yang lebih tinggi daripada $\mathrm{H}_{2}$ (g) sehingga lebih efisien untuk disimpan. Walaupun cairan, sudah tentu harus dipertahankan pada suhu rendah. Salah satu sistem penyimpanan yang lebih menguntungkan ialah dengan melarutkan $\mathrm{H}_{2}(\mathrm{~g})$ dalam logam. Gas kemudian dapat dibebaskan dengan pemanasan perlahan-lahan dari hibrida logamnya (Petrucci, 1985).

Logam-logam dalam golongan IA dan bagian bawah golongan IIA bersifat begitu reaktif sehingga bahkan dengan air dapat bereaksi dan menghasilkan hidrogen. Reaksi seperti ini hanya dihasilkan dengan aluminium, dengan adanya senyawa alkali yang kuat, seperti $\mathrm{NaOH}$ atau $\mathrm{KOH}$. Karena logam ini memiliki lapisan pasif yang sangat tipis $\mathrm{Al}_{2} \mathrm{O}_{3}$ pada permukaannya yang mencegah serangan langsung dari molekul air (Porciuncula, 2012). Reaksi antara aluminium dengan $\mathrm{KOH}$ dengan konsentrasi tertentu menghasilkan gas hidrogen, dimana tahap pertama akan terjadi endapan hidrolisa aluminium yang akan segera larut sebagai komplek aluminat. Larutan aluminat ini juga menghasilkan produk samping yaitu $\mathrm{KAlO}_{2}$ (tawas).

$$
2 \mathrm{Al}_{(\mathrm{s})}+2 \mathrm{KOH}_{(\mathrm{aq})}+2 \mathrm{H}_{2} \mathrm{O}(\mathrm{l}) \rightarrow 2 \mathrm{KAlO}_{2(\mathrm{aq})}+3 \mathrm{H}_{2}(\mathrm{~g})
$$


Pemutusan $\mathrm{Al}$ (s) dalam $\mathrm{KOH}$ encer adalah contoh dari reaksi oksidasireduksi atau reaksi redoks. Logam Al dioksidasi menjadi aluminium dengan bilangan oksidasi ${ }^{+} 3$ dan hidrogen dalam $\mathrm{KOH}$ atau dalam air. Hidrogen dapat dibuat atau diperoleh dengan mereaksikan logam-logam dengan asam kuat dan dengan logam aluminium yang direaksikan dengan basa kuat. Pada praktikum kali ini, pembuatan gas hidrogen dilakukan dengan menggunakan $\mathrm{KOH}$ dan limbah kaleng minuman, dimana $\mathrm{KOH}$ bertindak sebagai katalis yang mempercepat reaksi. Aluminium merupakan logam yang berwarna putih abu-abu (silver) yang melebur pada $659{ }^{\circ} \mathrm{C}$, dan bila terkena udara akan teroksidasi pada permukaannya. Pembentukan hidrogen ini terjadi menurut persamaan:

Alkaline solution

$$
2 \mathrm{Al}+6 \mathrm{H}_{2} \mathrm{O} \longrightarrow 2 \mathrm{Al}(\mathrm{OH})_{3}+3 \mathrm{H}_{2} \uparrow
$$

Ada beberapa keuntungan menggunakan aluminium sebagai sumber utama energi. Pertama, dengan produk $\mathrm{Al}(\mathrm{OH}) 3$ dapat digunakan untuk memproduksi garam aluminium lain untuk beberapa aplikasi, mulai dari pengolahan air (seperti $\mathrm{Al}_{2}\left(\mathrm{SO}_{4}\right)_{3}$ untuk penggunaan hidroksida dalam obat-obatan. Kedua, pemulihan aluminium dari $\mathrm{Al}(\mathrm{OH})_{3}$ dapat dilakukan dengan elektrolisis atau proses lain yang nyaman. Ketiga, aluminium dapat diperoleh dari bahan daur ulang, seperti minuman atau bir ringan kaleng (Martínez dkk, 2005). Keempat, derajat yang berbeda kemurnian logam dapat digunakan, sehingga paduan komersial bukan paduan tinggi kemurnian murni atau dapat digunakan. Kelima, hidrogen yang dihasilkan oleh reaksi (1) adalah murni; Oleh karena itu, dapat digunakan di perangkat yang membutuhkan kemurnian tinggi, termasuk beberapa jenis sel bahan bakar untuk perangkat elektronik portabel atau bahkan untuk aplikasi mobile. Intinya alkali tersebut tidak dikonsumsi dalam reaksi dan bertindak sebagai katalis, itu dapat dipulihkan sepenuhnya (Porciuncula, 2012).

Adapun tahapan reaksi antara aluminium, $\mathrm{KOH}$, dan air dalam U.S Department of Energy (2008) adalah sebagai berikut: 


$$
2 \mathrm{Al}+2 \mathrm{KOH}+2 \mathrm{H}_{2} \mathrm{O} \rightarrow \mathrm{K}_{2} \mathrm{Al}_{2} \mathrm{O}_{4}+3 \mathrm{H}_{2}
$$

$$
2 \mathrm{Al}+6 \mathrm{KOH}+\mathrm{xH}_{2} \mathrm{O} \rightarrow \mathrm{K}_{6} \mathrm{Al}_{2} \mathrm{O}_{6}+\mathrm{xH}_{2} \mathrm{O}+3 \mathrm{H}_{2}
$$

$2 \mathrm{Al}+2 \mathrm{KOH}+6 \mathrm{H}_{2} \mathrm{O} \rightarrow 2 \mathrm{KAl}(\mathrm{OH})_{4}+3 \mathrm{H}_{2}$

$$
2 \mathrm{KAl}(\mathrm{OH})_{4} \rightarrow 2 \mathrm{KOH}+2 \mathrm{Al}(\mathrm{OH})_{3}
$$

Hidrogen merupakan salah satu energi alternatif terbarukan yang mendapatkan perhatian untuk dikembangkan sebagai energi pengganti bahan bakar fosil. Energi bahan bakar hidrogen mempunyai keuntungan yaitu lebih ramah lingkungan dan lebih efisien. Suplai energi yang dihasilkan sangat bersih, karena hanya menghasilkan uap air sebagai emisi selama berlangsungnya proses (Gupta, 2009).

\section{Metode Penelitian}

Penelitian ini dilakukan melalui 2 tahap yaitu tahapan persiapan bahan baku dan tahap penelitian. Kaleng minuman coca-cola bekas dibersihkan/ dihilangkan terlebih dahulu catnya menggunakan amplas. Kemudian dipotong dengan ukuran $0,1 \quad \mathrm{~cm} \quad \mathrm{x} \quad 0,1 \mathrm{~cm}$ dan ditimbang dengan berat sampel divariasikan 0,5 gram, 1 gram, 1,5 gram dan 2 gram. $\mathrm{KOH}$ disiapkan dan diencerkan di dalam labu ukur $100 \mathrm{~mL}$ masing-masing dengan konsentrasi yang berbeda-beda yaitu $2 \mathrm{~N}, 3 \mathrm{~N}, 4 \mathrm{~N}, 5 \mathrm{~N}$ dan $6 \mathrm{~N}$. Potongan aluminium dimasukkan ke dalam erlenmeyer. Masing-masing larutan KOH $2 \mathrm{~N}$ sebanyak $25 \mathrm{~mL}$ direaksikan dengan potongan aluminium seberat 0,5 gram. Dipasangkan balon pada gelas erlenmeyer untuk menangkap gas hidrogen yang terbentuk dalam waktu 60 menit menggunakan stopwatch. Diamati suhu konstan pada $30^{\circ} \mathrm{C}$ dan pengadukan pada $100 \mathrm{rpm}$. Setelah mencapai waktu 60 menit, ikatkan balon menggunakan karet gelang. Proses di atas diulangi kembali untuk berat aluminium 1 gram, 1,5 gram dan 2 gram. Semua proses di atas diulangi kembali pada konsentrasi $3 \mathrm{~N}, 4 \mathrm{~N}, 5 \mathrm{~N}$, dan $6 \mathrm{~N}$. 
Sampel yang telah direaksikan dengan $\mathrm{KOH}$ tadi di dalam erlenmeyer, ditutup dengan balon agar $\mathrm{H}_{2}$ masuk ke dalam balon. Sehingga dapat dihitung volume $\mathrm{H}_{2}$ di dalam balon dengan mengukur terlebih dahulu keliling balon dari berbagai sisi karena bentuk balon yang tidak simetris dan diperoleh keliling ratarata balon dan juga jari-jari rata-rata balon, tersebut menggunakan persamaan berikut:

$$
\begin{aligned}
& \mathrm{K}=2 \cdot \mu \cdot \mathrm{r} \\
& \mathrm{V}=\frac{4}{3} \mu \mathrm{r}^{3} .
\end{aligned}
$$

dimana :

$$
\begin{array}{ll}
\mathrm{K} & =\text { Keliling balon rata-rata }(\mathrm{cm}) \\
\mathrm{R} & =\text { jari-jari balon rata-rata }(\mathrm{cm}) \\
\pi & =22 / 7 \text { atau } 3,14 \\
\mathrm{~V} & =\text { Volume } \mathrm{H}_{2}\left(\mathrm{~cm}^{3}\right)
\end{array}
$$

Kemudian konversi dan yield gas hidrogen yang diperoleh dihitung dengan menggunakan persamaan yang digunakan oleh Chirag and Pant (2011). Adapun persamaan tersebut adalah:

a. Konversi (X) adalah perbandingan mol reaktan yang bereaksi dengan mol reaktan yang masuk dan dihitung dengan persamaan berikut:

$$
\mathrm{X}_{\mathrm{A}}(\%)=\frac{\mathrm{m} \text { A } \mathrm{m}-\mathrm{m} \text { A K }}{\mathrm{m} \mathrm{A} \mathrm{m}} \times \text { Kemurnian } \mathrm{Al} \times 100 \%
$$

b. Besarnya yield (Y) hidrogen (\%) dari tiap-tiap variabel dapat ditentukan dengan membandingkan berat (massa) atau mol produk akhir (gas hidrogen) terhadap berat (massa) atau mol reaktan awal (aluminium).

$$
\mathrm{Y}(\%)=\frac{\mathrm{m} \mathrm{H} \mathrm{H}_{\gamma}}{\mathrm{m} \mathrm{H} \mathrm{H}_{2} \mathrm{C}} \times 100 \%
$$

Uji gas hidrogen dilakukan dengan penyulutan api terhadap gas $\mathrm{H}_{2}$ yang dikumpulkan dalam balon. Uji ini untuk membuktikan bahwa gas yang dihasilkan adalah gas $\mathrm{H}_{2}$ yang mempunyai titik nyala yang tinggi dan sangat mudah terbakar (flameable). Pengujian juga dilakukan dengan cara menyulut/ membakar langsung dari hasil reaksi antara aluminium dan api dengan bantuan $\mathrm{KOH}$. 


\section{Hasil dan Diskusi}

Pada umumnya, hidrogen dapat dihasilkan dari beberapa metode melalui proses biologi, elektrolisis atau dengan reaksi kimiawi. Metode yang digunakan pada penelitian ini ialah reaksi kimiawi antara potongan limbah kaleng minuman coca-cola dengan larutan $\mathrm{KOH}$ pada konsentrasi yang berbeda-beda.

\subsection{Pengaruh Konsentrasi KOH dan Berat Bahan Baku terhadap Volume $\mathbf{H}_{2}$}

Hasil volume gas hidrogen yang diperoleh telah dirangkum dalam Tabel 1 berdasarkan konsentrasi katalis dan berat bahan baku.

Tabel 1 Hasil volume gas $\mathrm{H}_{2}$

\begin{tabular}{|c|c|c|c|}
\hline $\begin{array}{c}\text { Konsentrasi KOH } \\
(\mathbf{N})\end{array}$ & $\begin{array}{c}\text { Berat Bahan Baku } \\
(\text { gram })\end{array}$ & $\begin{array}{c}\text { Volume } \mathbf{H}_{2} \\
\left(\mathbf{c m}^{3}\right)\end{array}$ & $\begin{array}{c}\text { Volume } \mathbf{H}_{2} \\
\left(\mathbf{m}^{3}\right)\end{array}$ \\
\hline \multirow{2}{*}{2} & 0,5 & 483,4 & $4,843.10^{-4}$ \\
& 1 & 756,3 & $7,563.10^{-4}$ \\
& 1,5 & 877,2 & $8,772.10^{-4}$ \\
& 2 & 1173,6 & $1,174.10^{-3}$ \\
\hline \multirow{3}{*}{3} & 0,5 & 503,6 & $5,036.10^{-4}$ \\
& 1 & 863,2 & $8,632.10^{-4}$ \\
& 1,5 & 1234,6 & $1,235 \cdot 10^{-3}$ \\
& 2 & 1410,7 & $1,411.10^{-3}$ \\
\hline & 0,5 & 559,1 & $5,591.10^{-4}$ \\
& 1 & 905,8 & $9,058.10^{-4}$ \\
& 1,5 & 1334,6 & $1,335.10^{-3}$ \\
& 2 & 1743,8 & $1,744.10^{-3}$ \\
\hline \multirow{3}{*}{5} & 0,5 & 569,6 & $5,696.10^{-4}$ \\
& 1 & 964,7 & $9,647.10^{-4}$ \\
& 1,5 & 1410,7 & $1,411.10^{-3}$ \\
& 2 & 1869,4 & $1,869.10^{-3}$ \\
\hline \multirow{2}{*}{6} & 0,5 & 602,0 & $6,020.10^{-4}$ \\
& 1 & 987,4 & $9,874.10^{-4}$ \\
& 1,5 & 1479,6 & $1,480.10^{-3}$ \\
& 2 & 2025,5 & $2,025.10^{-3}$ \\
\hline
\end{tabular}

Pada konsentrasi $2 \mathrm{~N}$ dengan berat bahan baku 0,5 gram diperoleh volume gas hidrogen sebesar $4,843.10^{-4} \mathrm{~m}^{3}$, pada 1 gram diperoleh sebesar $7,563.10^{-4} \mathrm{~m}^{3}$, pada 1,5 gram gas hidrogen yang diperoleh sebesar $8,772.10^{-4} \mathrm{~m}^{3}$ dan pada 2 gram diperoleh gas hidrogen sebesar $1,174.10^{-3} \mathrm{~m}^{3}$. Gambar 1 menunjukkan bahwa semakin besar konsentrasi $\mathrm{KOH}$ maka semakin besar pula volume gas hidrogen yang diperoleh dan sesuai dengan hasil penelitian Porciuncula dkk (2012). Efek 
perpindahan massa ini adalah hasil dari interaksi kompleks antara pengendapan $\mathrm{Al}(\mathrm{OH})_{3}$ pada logam dan pergerakan gelembung hidrogen melalui lapisan pasivasi dan $\mathrm{KOH}$. Selain itu, hal ini juga dikarenakan larutan $\mathrm{KOH}$ membantu $\mathrm{Al}$ mengikat $\mathrm{OH}^{-}$dari $\mathrm{H}_{2} \mathrm{O}$ dan membentuk $\mathrm{KAl}(\mathrm{OH})_{4}$, dan melepaskan $\mathrm{H}_{2}$, seperti yang telah disimpulkan oleh Kumar dan Surenda, (2013).

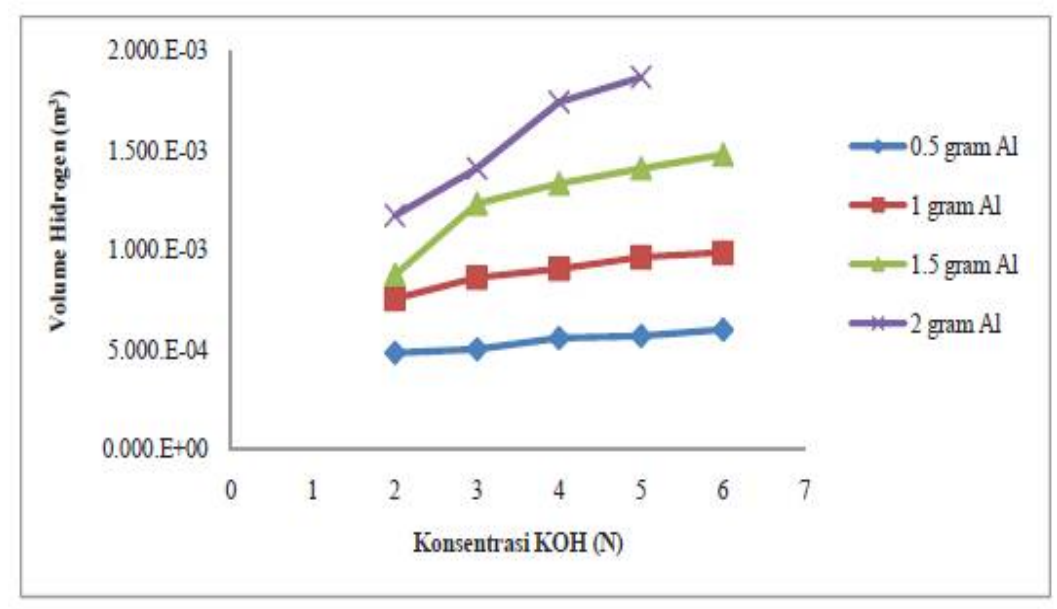

Gambar 1 Hubungan konsentrasi $\mathrm{KOH}$ dan volume hidrogen

Jumlah bahan baku juga dapat mempengaruhi volume gas hidrogen yang diperoleh seperti yang terlihat pada Gambar 1 di atas bahwa semakin besar jumlah bahan baku maka semakin besar pula gas hidrogen yang diperoleh. Kemungkinan hal ini terjadi karena perubahan bilangan oksidasi aluminium dan hidrogen. Al membentuk ion $\mathrm{Al}(\mathrm{OH})_{4}{ }^{-}$berarti bilangan oksidasinya berubah dari nol menjadi +3. Sedangkan bilangan oksidasi $\mathrm{H}$ dari ${ }^{+} 1$ menjadi nol. Berarti, baik dalam asam maupun basa, reaksi redoks yang terjadi sebagai akibat dari sifat keamfoteran $\mathrm{Al}$, ternyata perubahan bilangan oksidasinya sama.

\subsection{Pengaruh konsentrasi KOH dan berat bahan baku terhadap Yield $\mathrm{H}_{2}$}

Yield perlu dihitung untuk mengukur derajat sampai dimana reaksi yang diinginkan berjalan relatif terhadap reaksi pesaing alternatif (reaksi yang tidak diinginkan). Hubungan antara konsentrasi $\mathrm{KOH}$ dengan yield hidrogen yang dihasilkan dapat dilihat pada Gambar 2.

Pada Tabel 2 dapat dilihat bahwa 0,5 gram potongan limbah kaleng minuman dengan $\mathrm{KOH} 2 \mathrm{~N}$ dihasilkan gas hidrogen sebesar 1,54 \%, pada $\mathrm{KOH} 3$ $\mathrm{N}$ dengan jumlah berat bahan baku yang sama diperoleh gas hidrogen 1,64\%, 
pada $\mathrm{KOH} 4 \mathrm{~N}$ diperoleh gas hidrogen sebesar 1,88 \%, pada $\mathrm{KOH} 5 \mathrm{~N}$ diperoleh gas hidrogen sebesar 1,97\%, dan pada $\mathrm{KOH} 6 \mathrm{~N}$ diperoleh gas hidrogen sebesar $2,15 \%$.

Semakin besar konsentrasi $\mathrm{KOH}$ maka yield hidrogen yang diperoleh semakin tinggi, seperti yang terlihat pada Gambar 3. Hal ini terjadi dikarenakan semakin cepat reaksi $\mathrm{KOH}$ mengikat aluminium dan oksigen dari air sehingga semakin banyak gas hidrogen yang terlepas dari air tersebut.

Tabel 2 Hasil analisa yield $\mathrm{H}_{2}$

\begin{tabular}{|c|c|c|}
\hline $\begin{array}{c}\text { Konsentrasi Katalis } \\
(\mathbf{N})\end{array}$ & $\begin{array}{c}\text { Berat Bahan Baku } \\
\text { (gram) }\end{array}$ & $\begin{array}{c}\text { Yield } \mathbf{H}_{\mathbf{2}} \\
(\mathbf{\%})\end{array}$ \\
\hline \multirow{2}{*}{2} & 0,5 & 1,54 \\
& 1 & 2,40 \\
& 1,5 & 2,78 \\
3 & 2 & 3,72 \\
\hline \multirow{3}{*}{4} & 0,5 & 1,64 \\
& 1 & 2,82 \\
& 1,5 & 4,03 \\
& 2 & 4,60 \\
\hline \multirow{3}{*}{5} & 0,5 & 1,88 \\
& 1 & 3,04 \\
& 1,5 & 4,48 \\
& 2 & 5,86 \\
\hline \multirow{2}{*}{6} & 0,5 & 1,97 \\
& 1 & 3,34 \\
& 1,5 & 4,88 \\
& 2 & 6,47 \\
\hline & 0,5 & 2,15 \\
& 1 & 3,52 \\
& 1,5 & 5,28 \\
& 2 & 7,23 \\
\hline
\end{tabular}

Pada konsentrasi KOH yang sama, semakin besar jumlah bahan baku maka semakin besar juga yield yang dihasilkan dan secara stoikiometri hal ini adalah benar. Pada konsentrasi $2 \mathrm{~N}$ dengan berat bahan baku 0,5 gram diperoleh gas hidrogen sebesar 1,54 \%, pada 1 gram diperoleh sebesar 2,40\%, pada 1,5 gram gas hidrogen yang diperoleh sebesar $2,78 \%$ dan pada 2 gram diperoleh gas hidrogen sebesar 3,72\%. Peningkatan yield tersebut dapat terjadi dikarenakan $\mathrm{OH}^{-}$dari senyawa air banyak diikat oleh aluminium dan melepaskan gas hidrogen. 


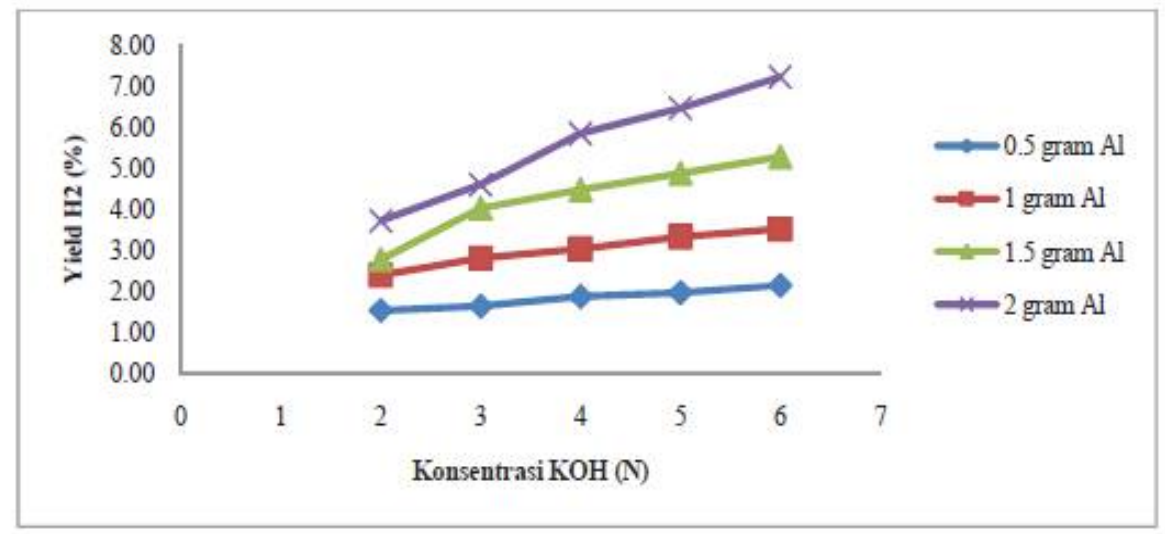

Gambar 2 Hubungan konsentrasi $\mathrm{KOH}$ dan yield $\mathrm{H}_{2}$

\subsection{Pengaruh konsentrasi KOH dan bahan baku terhadap konversi Al}

Untuk hasil konversi aluminium yang diperoleh telah dirangkum dalam

Tabel 3 berdasarkan konsentrasi katalis dan berat bahan baku.

Tabel 3 Hasil analisa konversi Al

\begin{tabular}{|c|c|c|}
\hline $\begin{array}{c}\text { Konsentrasi Katalis } \\
(\mathbf{N})\end{array}$ & $\begin{array}{c}\text { Berat Bahan Baku } \\
(\text { gram })\end{array}$ & $\begin{array}{c}\text { Konversi Al } \\
(\%)\end{array}$ \\
\hline \multirow{2}{*}{2} & 0,5 & 50,60 \\
& 1 & 39,07 \\
& 1,5 & 26,49 \\
& 2 & 18,99 \\
\hline 3 & 0,5 & 63,78 \\
& 1 & 50,42 \\
& 1,5 & 40,55 \\
4 & 2 & 33,94 \\
\hline \multirow{3}{*}{5} & 0,5 & 72,80 \\
& 1 & 60,80 \\
& 1,5 & 51,06 \\
& 2 & 42,34 \\
\hline \multirow{2}{*}{6} & 0,5 & 77,31 \\
& 1 & 71,29 \\
& 1,5 & 65,02 \\
& 2 & 57,14 \\
\hline
\end{tabular}


Pada konsentrasi KOH $2 \mathrm{~N}$ dengan berat bahan baku 0,5 gram potongan aluminium yang terkonversi sebesar 50,60 \%, pada KOH $3 \mathrm{~N}$ sebesar 63,78 \%, dengan berat bahan baku yang sama pada $\mathrm{KOH} 4 \mathrm{~N}$ konversi sebesar 72,80\%, pada KOH 5 N sebesar 77,31 \%, dan pada KOH 6 N konversi sebesar 86,97 \%. Untuk hubungan konsentrasi $\mathrm{KOH}$ dan jumlah bahan baku yang divariasikan dengan konversi aluminium menjadi produk dapat dilihat pada Gambar 3.

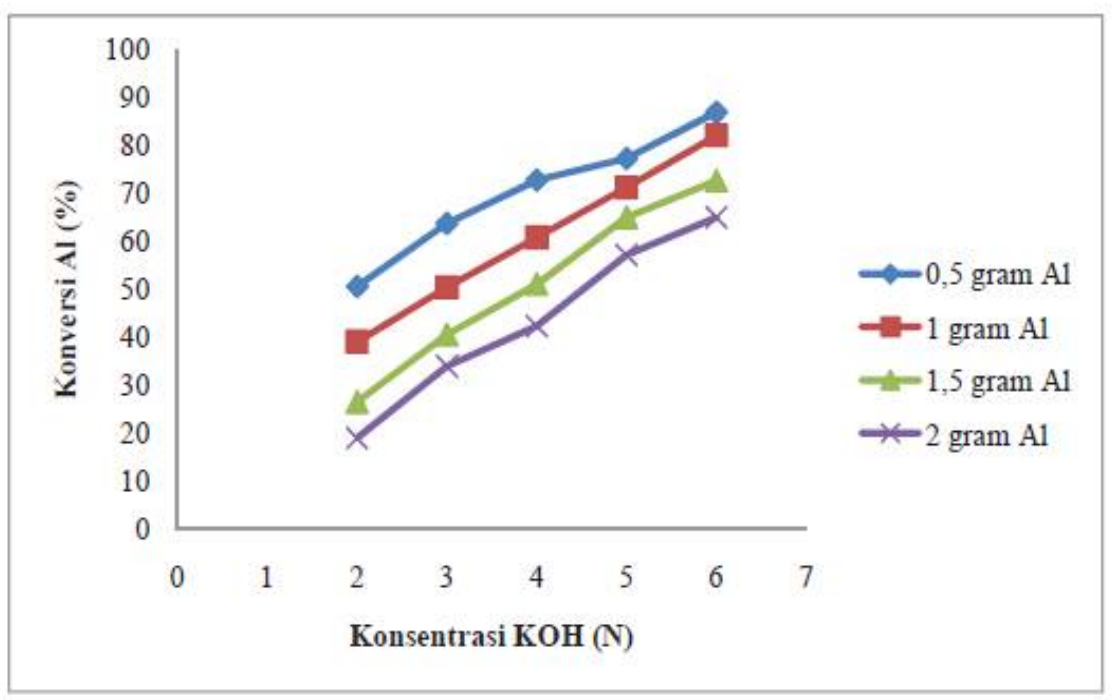

Gambar 3 Hubungan konsentrasi KOH dan konversi

Semakin besar konsentrasi $\mathrm{KOH}$ yang digunakan dalam penelitian ini, maka semakin besar konversi aluminium yang diperoleh seperti yang ditunjukkan pada Gambar 3. Hal tersebut dikarenakan $\mathrm{KOH}$ merupakan katalis reaktif yang dapat merusak lapisan oksida $\left(\mathrm{Al}_{2} \mathrm{O}_{3}\right)$ pelindung pada permukaan aluminium serta membantu $\mathrm{Al}$ mengikat $\mathrm{OH}^{-}$dari $\mathrm{H}_{2} \mathrm{O}$ dan membentuk $\mathrm{KAl}(\mathrm{OH})_{4}$ serta melepaskan $\mathrm{H}_{2}$. Katalis cair yang digunakan adalah ion yang mendorong terjadinya reaksi sehingga semakin besar katalis yang digunakan maka semakin banyak ion yang mendorong terjadinya reaksi sehingga konversi semakin besar (Okvitarini dkk, 2013).

Gambar 3 juga menunjukkan bahwa semakin besar jumlah bahan baku yang dicampurkan dalam reaksi maka konversi yang dihasilkan semakin rendah. Pada konsentrasi $\mathrm{KOH}$ yang sama yaitu pada $2 \mathrm{~N}$ dengan berat bahan baku 0,5 gram potongan aluminium diperoleh konversi sebesar 50,60 \%, pada 1 gram diperoleh konversi sebesar 39,07 \%, pada 1,5 gram diperoleh konversi sebesar 26,49\%, dan 
pada 2 gram potongan aluminium dengan konsentrasi $\mathrm{KOH}$ yang sama diperoleh konversi sebesar $18,99 \%$.

Gas hidrogen yang diperoleh dapat juga dibuktikan dengan pembakaran (disulut dengan api), karena hidrogen bersifat sangat mudah terbakar dan akan terbakar pada konsentrasi serendah 4\% di udara bebas (Khairunnisa, 2013). Gas hidrogen bersifat mudah terbakar dan dalam penelitian ini gas hidrogen sudah terbentuk. Berdasarkan persamaan teoritis dalam reaksi, hidrogenlah yang bersifat sangat mudah terbakar.

\section{Simpulan}

1. Gas hidrogen dapat diproduksi dari campuran aluminium, air dengan bantuan $\mathrm{KOH}$ sebagai katalis.

2. Volume gas hidrogen paling besar diperoleh pada konsentrasi $6 \mathrm{~N}$ dengan berat bahan baku 2 gram yaitu sebesar $2,025.10^{-3} \mathrm{~m}^{3}$.

3. Yield gas hidrogen tertinggi diperoleh pada konsentrasi $6 \mathrm{~N}$ dengan berat bahan baku 2 gram yaitu sebesar 7,23\%.

4. Konversi Al menjadi produk baik produk utama maupun produk samping, diperoleh konversi tertinggi pada konsentrasi $6 \mathrm{~N}$ dengan berat bahan baku 0,5 gram yaitu sebesar $86,97 \%$.

\section{Daftar Pustaka}

Agus, W. Dan Jajang, J. 2014. Pemanfaatan Hidrogen Hasil Reaksi Water Replacement Berbahan Baku Kaleng Bekas Untuk Bahan Bakar Mesin Diesel Sistim Dual Fuel. Pekanbaru: Politeknik Caltex Riau

Chirag, D. D., and Pant, K. K. 2011. Renewable Hydrogen Generation by Steam Reforming of Glycerol Over Zirconia Promoted Ceria Supported Catalyst. Journal Renewable Energy xxx (1-8).

Galih, G. 2015. Coca-cola Incar Produksi 450 Juta Liter Minuman di Indonesia. http://www.cnnindonesia.com/ekonomi/20150331174226-92-43310/cocacola-incar-produksi-450-juta-liter-minuman-di-indonesia/diakses 19 Desember 2015.

Gupta, R. B. 2009. Hydrogen Fuel Production, Transport, and Storage. CRC press, USA, 17-29 
Henry, C. 1766. Papers Containing Experiments on Factitious Air. Philosophical Transactions (The University Press) 56: 141.184.

Khairunnisa. 2013. Hidrogen dan Golongan IV A. Bandung: Universitas Pendidikan Indonesia.

Kumar, S., Surendra, K. S. 2013. Role of Sodium Hydroxide for Hydrogen Gas Production and Storage. USA: Florida International University

Louis, M, Ed. 1963. Handbook of Analytical Chemistry. New York: McGrawHill, New York.

Martinez, S. S., Benitesa, W.L., Gallegosa, A., Sebastian, P. J. 2005. Recycling of Aluminium to Produce Green Energy. Solar Energy Mater Solar Cell 88:237-243.

Okvitarini, N., Makrufah, H. I., Hantoro, S., dan Widayat. 2013. Pembuatan Biodiesel dari Minyak Goreng Menggunakan Katalis KOH dengan Penambahan Ekstrak Jagung. Semarang: Universitas Diponegoro.

Petrucci, R. H. 1985. General Chemistry. Principles and Modern Application Fourth Edition. San Bernadino: Collier Macmilan,Inc.

Porciuncula, C. B., Marcilio, N. R., Tessaro, I. C., and Gerchmann, M. 2012. Production of Hydrogen in the Reaction between Aluminium and Waterin the Presence of $\mathrm{NaOH}$ and $\mathrm{KOH}$. Federal University of Rio Grande do Sul. Braz. J. Chem. Eng. Vol.29 No.2.

Siregar, Y. D. I. 2010. Produksi Gas Hidrogen dari Limbah Aluminium. Jurnal Valensi. Volume 2, No. 1, 362-36.

U.S Department of Energy. 2008. Reaction of Aluminium with Water to Produce Hydrogen Version 1.0. United State of America. 